\title{
POISONS, POISONING AND THE DRUG TRADE IN ANCIENT ROME
}

\author{
L Cilliers \& F P Retief (University of the Free State)
}

\begin{abstract}
SUMMARY
The first recorded instance of poisoning in ancient Rome occurred in $331 \mathrm{BC}$ when, during an epidemic, a large number of women were accused of concerted mass poisoning. Overreaction of the community in times of stress particularly, when scapegoats for unexplained phenomena are sought, might have played an important role in this and many subsequent incidents of suspected poisoning. Rome represented a culture steeped in superstition, fear and mythology with virtually no scientific means of retrospectively proving or disproving alleged poisoning. The drug trade in antiquity is briefly reviewed, from the Marsi and rootcutters who collected materials, and the intermediary herbalists and drug pedlars, to the physicians and other prescribers of drugs. There was a general lack of proper knowledge, which led to much abuse and death of patients. The distinction between these professional groups was often vague and physicians were generally not held in high regard. From authoritative writings of Theophrastus, Dioscorides, Pliny and others it is evident that the Romans were aware of a very large number of toxic (and assumed toxic) substances, of plant, animal and mineral origin, but it is evident that the poisoners of ancient Rome almost exclusively made use of plant (and to lesser extent animal) products, and not mineral poisons. A brief overview of the recorded crimes by poison, and known poison dispensers of the time is given. Poisoning probably reached a maximum during the 1 st and 2 nd centuries AD, when the Julio-Claudian emperors in particular achieved great notoriety, and a wide variety of specific and "universal" antidotes came into vogue.
\end{abstract}

The history of poisons and poisoning goes back about 5000 years to the earliest written records of the human race. Menes, first of the Pharaohs, approximately 3000 years BC studied and cultivated poisonous and medicinal plants - an interest retained by the Egyptian court (Smith 1952:153), until the last Pharaoh, Cleopatra, probably died of suicide by poisoning (Retief \& Cilliers 1999:8-11). The cuneiform writings of early Mesopotamia mention the use of poisons - a topic also dealt with in the written records of ancient India and China. Early Greek myths tell of poisoners like Medea and Hercules' wife Deianira, and in the 5th century BC execution by poison was accepted in Athenian law courts. In the Hippocratic oath, nevertheless, the students of the great master are made to swear that they will not use poison (Lloyd 1983:67). The Persian court was proficient in the art of poisoning (Smith 1952:155), while Mithridates VI, king of Pontus at the turn of the first century BC and Attalus III, last king of Pergamum in the second century, experimented with poisons on condemned prisoners (Bloch 1987: 761-763).

In Rome the first record of poisoning dates back to $331 \mathrm{BC}$ when a large number of women were executed for suspected mass poisoning. Although we shall 
never know its true incidence, there is good evidence that poisoning occurred more and more frequently among all levels of society, reaching a peak in the 1 st and 2nd centuries $\mathrm{AD}$. In $80 \mathrm{BC}$ the dictator Sulla promulgated strict laws against poisoning. ${ }^{1}$ At the end of the 1st century AD the satirist Juvenal and others denounced their decadent society, claiming that poisoning had become a status symbol, an accepted way for mothers to get rid of husbands and stepchildren, and for children to get rid of rich fathers who lived too long (Juv. 1.73-76; 6.133 and 602-643; 7.169; 14.250-255).

Kaufman (1932:156) states that the word venenum (venom) is derived from Venus and originally meant a love potion. In actual usage it later had three meanings: remedy, poison and magic drug or abortive; in fact, venenum is such an ambiguous word that jurists demanded that "the user of the word venenum must add whether it is beneficial or harmful". 2 The Greek word pharmakon likewise referred to herb or drug in general without distinguishing between its beneficial or harmful effects (Horstmanshoff 1999:43). Veneficium meant poisoning or practicing sorcery, while veneficus or venefica referred to a poisoner or preparer of drugs. The word scelus (crime) is actually used by historians like Tacitus to indicate murder by poison (Ann. 1.5.2; 4.10.2; 6.33.1; 12.66.3). Poisons were also used for suicide - royalty in particular kept a supply for emergencies (Kaufman 1932:160). Pliny considered it quite proper for the infirm elderly to end his or her miserable life by taking poison, and opium in particular (NH 2.197; 20.197-199).

\section{The drug trade}

Differentiation between producers of drugs (including poisonous substances), sellers and prescribers of drugs in antiquity was much less clear cut than today. There were, however, distinct intermediaries in this drug trade who played specific roles, as summarised by Nutton (1985:138-145).

The Marsi or "travelling people" were at one end of the production chain. Inhabiting the Abruzzi (central mountainous area of Italy), they had a reputation of being wild and warlike with strange and archaic religious practices. They lived in poverty, were excellent soldiers in the Roman army, but their only civilian attributes lay in almost legendary magical powers as snake hunters and charmers, and druggists. In many ways they were marginal people, who paid periodic visits to the cities, selling their wares in the markets and performing daring acts as snake charmers. They were reputed to have immunity against snake venom, and Galen admits to consulting them on the value of drugs and antidotes. The Psylli, Nasamones and Palaeothebans were similar peoples living elsewhere in the Mediterranean region, respected for their skills with drugs, but frowned on by the early Christians who felt that they should not be admitted to the flock without the greatest circumspection.

1 Although there existed a Quaestio de veneficiis before the time of Sulla (Dessau ILS 45), the iudicia publica (among which the Quaestio de sicariis et veneficiis) instituted by Sulla were properly organized in that penalties were fixed and no appeal against the verdict was possible (Scullard 1982:83 and 415-416 n.45.

Digesta 50.16.236. Reference thanks to Horstmanshoff 1999:43-44. 
The so-called rootcutters (rhizotomoi) were much more acceptable to society as true herbalists who knew and collected plant products, which were sold to physicians and other interested parties. Some of them were recognized experts, including the respected 1st century BC pharmacologist, Crataeus, assistant to Mithridates. Most large cities had quarters frequented by the sellers of drugs (including those inducing euphoric trances ${ }^{3}$ and poisons) and hawkers (called an agurtês, "the man who attracts a crowd" or ochlagôgos, "seducer of the crowd"), as well as physicians in search of remedies, and a motley crowd in search of pleasures associated with the variety of ointments, perfumes and spices. Gradually the drug trade became very lucrative and expanded by way of contact with the Far East, Egypt, Arabia, North Africa and Spain. In Rome these imported products were stored in apothecae (derived from a Greek word which literally means "storeroom"), where the storeman (apothecarius) would list them.

Eventually the lucrativeness of the drug trade led to widespread fraud and incompetence. Galen and others insisted that physicians should prepare their own medicines, and not rely on herbalists to do so. As poisoning increased, there was a growing trade in mithridatum, theriac and other so-called antidotes to poison. However, Nutton (1985:144-145) points out that wide-spread and basic ignorance about the action of medications led to the situation where the drug trade was financially profitable, but from a medical point of view ineffective and even disastrous.

As from the late 1st century $\mathrm{BC}$ certain persons (mostly women) became infamous as dispensers of poison. The poet Horace (Sat. 2.1.56) tells of Canidia who terrorized her opponents with her efficiency at poisoning. Tacitus (Ann. 2.69-74; 3.7) relates that when the emperor Tiberius' nephew Germanicus died under suspicious circumstances (AD 19), it was suspected that the notorious poisoner, Martina, a close friend of Plancina, the wife of governor Piso who had quarreled with Germanicus, was partially responsible. Martina was sent to Rome where the Senate planned an investigation into Germanicus' death. She suddenly died on the way. Her body bore no signs of suicide, but poison was found hidden in a knot of her hair. Apollodorus, a rhetorician of Pergamum, was convicted as poisoner, but he escaped to Massilia where he opened a school (Kaufman 1932:165). Locusta was the most infamous of these poisoners (Suet. Nero 33.3; 34; Claudius 44). Convicted of many crimes during Claudius' reign, she was not immediately executed, and subsequently approached by Agippina, second wife of Claudius, to prepare a poison for her husband. When Claudius died, he was immediately succeeded by Nero, Agrippina's own son - who then engaged Locusta to prepare a poison for his younger half-brother, Britannicus. After the latter's murder, Nero suspended Locusta's death penalty and kept her as the emperor's adviser on poisons. He even organized a school of poisoning where she could train others in her art. Locusta was allowed to test her poisons on animals and convicted criminals.

According to Rutten (1997:32) the "top ten" drugs in Roman times inducing euphoric trances when used in extremely low dosages were opium, mandragora, henbane, belladonna, thorn apple, hemlock, aconite, cannabis sativa (dagga), alcohol, and poisonous mushrooms. 


\section{Known poisons}

Our knowledge of poisonous substances known to the ancient Romans is derived from the records of various contemporary writers. The Greek physician Diocles of Carystus (4th century BC) wrote an important book on botany of which we have fragments (Sigerist 1971:38-39), but Theophrastus, associate and successor of Aristotle as head of the Lyceum (4th century BC), led the way in identifying plants with medicinal (and poisonous) properties (Smith 1952:154). In the 1st century AD Dioscorides wrote his famous De Materia Medica which superseded all existing literature in classifying remedies and drugs from the animal, vegetable and mineral kingdoms. This work which dealt with close on 1000 drugs, became the standard text for centuries to come. Information on poisons can also be gleaned from the writings of Scribonius Largus (AD 1-50), Pliny the Elder (AD 23-79) and the poet Nicander (2nd century AD).

The following substances regarded as potentially lethal for man are mentioned by at least one of the above authors. The toxic clinical picture produced by these substances, is briefly discussed in the light of present knowledge. ${ }^{4}$

1. Vegetable origin

(i) Henbane (Hyoscyamus niger). Symptoms: Rapid onset of dry mouth, abnormally rapid heart beat and a progression of neurological symptoms varying from sedation to delirium, hallucination, mania, paralysis, coma and death.

(ii) Thorn apple (Datura stramonium). Symptoms: Rapid onset (within minutes of ingestion) with clinical picture as for henbane. Seeds produce mainly maniacal symptoms, white leaves tend towards stupor and coma. Survivors have amnesia of the event.

(iii) Deadly nightshade (Atropa belladonna). Three berries said to be fatal for a child. Symptoms as for henbane. Pliny (NH 21.177-182) refers to this plant as strychnos or trychnos, and mentions that spears were dipped in it. It was also taken by priests and others who wished to go into temporary trances.

(iv) Mandrake, mandragora. Atropa mandragora. Symptoms include dry mouth and rapid heart beat, but neurologically it caused sedation, motor depression and twilight sleep, rather than excitation and delirium, as with previous drugs. The toxins are mainly in the prominent root, which is long, often split into two, and reminded the ancients of the human figure. There was a widely shared belief that gathering the root was dangerous, as the plant, when uprooted, uttered a shriek, which caused the death or insanity of those who heard it. The root was thus merely loosened with a digger, and then attached to

$4 \quad$ For a detailed discussion of each of the poisons cf. Gilman et al 1985; Frohne \& Pfander 1983; and Watt \& Breyer-Brandwijk 1962. 
a dog, which completed the uprooting process but then fell down dead (Guthrie 1958:116).

(v) Aconite, Monk's hood (Aconitum napellus). Extremely poisonous even in small doses. Symptoms: Rapid onset of numbness and tingling of the mouth and throat which spreads over the rest of the body; pain and twitching of the muscles, progressing to general weakness, cold and clammy extremities, irregular heart rhythm and abnormally low blood pressure, respiratory paralysis, drowsiness (occasionally convulsions), stupor and death.

(vi) Hemlock (Conium maculatum). Symptoms: Rapid onset of nausea, salivation and vomiting, abdominal pain, headache and degrees of mental confusion. General weakness may be associated with convulsions, and death is caused by progressive paralysis and respiratory failure.

(vii) Hellebore. The name hellebore was given to a number of toxic plants, the precise identification of which still causes confusion.

Helleborus niger. Symptoms: Rapid onset of tingling of the mouth, salivation, vomiting, colic and diarrhoea. Dilation of pupils is common.

White hellebore. (Veratrum album). Very toxic. Symptoms: Rapid onset of tingling over the whole body, sneezing, vomiting and diarrhoea, followed by abnornally low blood pressure, cardiovascular collapse and respiratory paralysis which may cause death.

Black hellebore. Veratrum nigrum. Similar to white hellebore, except that in Europe this variety grows only south of the Alps. According to Pliny ( $\mathrm{NH}$ 25.53) this plant had to be gathered in a special way whilst looking to the east and with no eagles overhead.

(viii) Colchicum, autumn crocus (Colchicum autumnale). Symptoms: Tingling of the whole mouth and throat after 2-6 hours, is followed by an impaired ability to swallow, nausea, vomiting and diarrhoea (often bloody). Circulation collapse may follow, with general paralysis, often convulsions and even death due to respiratory failure.

(ix) Yew (Taxus baccato). Symptoms: After approximately one hour there is onset of dizziness, vomiting, rapid heart beat, dilation of the pupils, dilation of the superficial blood vessels causing a reddish face, and shallow breathing. Death results from respiratory paralysis. Pliny $(N H$ 16.50-51) claimed that even sleeping or resting under the tree could be fatal, but the yew became harmless once a copper nail had been driven into it. He also mentions that arrows were dipped in yew-sap to make them poisonous (apparently a reference to a Scythian custom, as quoted by Aristotle, Mir. 837a13), and that that some people thus used the word "taxic" when referring to poisons (from taxus $>$ a yew), but that in his own time the word "toxic" was in use (derived from the Greek words to toxikon pharmakon meaning "arrow poison").

(x) Opium. Papaver somniferum. Symptoms: A somniferous state with euphoria and pinpoint pupils, progressing to stupor with muscular relaxation, slow respiration and ultimately death from respiratory failure. Pliny $(N H$ 20.197- 
199) tells us that opium was often used by the elderly infirm to commit suicide.

(xi) Mushrooms. Amonita muscaria, A. pantherina and A. phalloides are the commonest poisonous mushrooms, and probably also existed in ancient times. A.muscaria. Symptoms: Within minutes to 2 hours, salivation, excessive production of tears, breathing problems and severe abdominal pain with diarrhoea, set in. Cardiovascular decompensation, vertigo and progressive mental symptoms like confusion, delirium, excitement (occasionally convulsions) may lead to coma and death within hours.

A.pantherina. Symptoms: Like A.muscaria, but with slower onset and higher fatality.

A.phalloides. Symptoms: Latent period of 6-15 hours is followed by abdominal pain, vomiting and diarrhoea (often bloody). Hepato-renal failure then sets in with death 2-3 days later, usually in hepatic coma.

The ancients could not really distinguish between edible and poisonous mushrooms. Dioscorides (Osbaldeston 2000:337 and 580) thought that an unhealthy environment made harmless mushrooms toxic, whilst Pliny ( $\mathrm{NH}$ 22.92-99) said that they became poisonous once a snake had breathed on them.

(xii) Other plants. Smith (1952:155) mentions oleander as a poison known to the ancients; Dioscorides (Osbaldeston 2000:580) mentions (wrongly) that oleander is toxic only for animals and not for man. No evidence could be found for Horstmanshoff's claim (1992:40) that coriander was used as poisons by the Romans. ${ }^{5}$ Kaufman (1932:162) mentions thapsia as very poisonous, but whilst stressing its blistering effect on exposed skin, Dioscorides (Osbaldeston 2000:637) refers to it only as a useful medicine for various conditions. Smith (1952:153-154) suggests that hydrogen cyanide was extracted from the kernels of certain fruits like almonds (as early as 400 BC) and used by Roman poisoners. However, we could find no evidence to corroborate its usage in ancient Rome. Strychnine comes from the nux vomica plant discovered in the 17th century - it was unknown to the ancients (Thompson 1931:73).

\section{Animal origin}

The ancients did not investigate poisons of animal origin as methodically as plant poisons. Obviously many of the claims were indeed based on myth and hearsay. The following poisonous animals were mentioned:

(i) Spanish fly, Blistering beetle (Cantharis vesicatoria), mentioned by Pliny ( $\mathrm{NH}$ 24.93-6). Symptoms: Depending on the dose ingested, the symptoms may be

Dioscorides 3.71 believed that an excessive use of coriander affected the brain, and apparently Scribonius Largus regarded it as poisonous. No modern evidence could be found for its believed toxicity. 
restricted to irritation and pain of the bladder and urethra - the latter may cause priapism, and for this reason it was widely (and ineffectually) used as an aphrodisiac. Bigger doses cause abdominal pain, vomiting and diarrhoea leading to shock. Death may occur due to renal or multi-organ failure. It also causes intense blistering of the skin.

(ii) Snakes. Pliny ( $N H$ 29.66-68) differentiated between various kinds of poisonous snakes, e.g. viper, aspis, dipsas and hydri (amphibious snakes). Snake venom was occasionally used as an oral poison. Today we know that snake venom taken by mouth is innocuous. Galen is quoted (Hughes-Hallett 1997:141) as saying that execution by snake bite was considered a humane practice in Alexandria of old, and Plutarch (Ant. 86) suggested that Cleopatra committed suicide through the bite of an asp. Otherwise there is little evidence that snake bite or snake venom played a significant role as homicidal procedures in ancient Rome.). Aristotle (Mir. 837a13) claimed that the Scythians used a deadly arrow poison concocted from a mixture of decomposed snake tissues and decomposing human blood.

(iii) Poisonous spiders and scorpions were recognized and a variety of antidotes described (Plin. NH 28.43; 29.81-84). A spotted ghecko was said to have a very poisonous bite (Plin. $N H$ 29.66-68).

(iv) Marine animals considered poisonous included the lagos, lepus marinus, dorycnium, arancus and trygon (unknown to us today); the lepus marinus (sea-hare) apparently belonged to the gastropod family (Plin. NH 9.155).

(v) Poisonous qualities claimed for the following animals were almost certainly fictitious:

The salamander was not described as lethal by Dioscorides (Osbaldeston 2000:199), but Pliny (NH 29.71-78) considered it the most wicked of all venomous creatures. By simply climbing into fruit trees and thus poisoning the fruit it could kill whole tribes unawares. By touching the water it would poison a well, and by touching a stone it could kill all those who subsequently touched the stone. However, salamander meat taken with honey was an aphrodisiac. Today we know that Salamandia maculosa has a poisonous skin, but the vast majority of salamanders are quite harmless (Thompson 1931:105).

According to Pliny, the basilisk could kill a man by merely looking at him (NH 29.66-68). Dioscorides does not mention it.

The blood of bulls, snakes and gelded goats was considered toxic for man as well as the meat of the wild weasel and shrew mouse (Plin. NH 20.122-6; 31.119).

The toad was considered dangerous - in particular toad's lung and toad's blood (Juv. 1.70). The South American toad, ceratophrys ornata, has a venomous bite, but virtually all other toads are harmless (Thompson 1931:103). Their ancient reputation probably derived from a repulsive appearance. 
3. Mineral origin

In Roman times toxic minerals played a minor role as deliberate poisons, but potentially fatal substances were well described.

(i) Lead was known to be poisonous for man and occurred as cerussite (lead carbonate) used as white paint for ships, and ceruse or cerussa (white lead, lead acetate) used as white pigment. Vapour from the lead smelting process was poisonous for man, animals and insects (Plin. $N H$ 28.4; 34.167) Dioscorides (Osbaldeston 2000:129, 187, 288) referred to "letharge" (probably lead oxide) which had both toxic and curative properties. Acute lead poisoning typically causes thirst, abdominal pain, vomiting and diarrhoea, shock, muscle pain and weakness, and kidney failure. Death may follow in 1-2 days. Nicander is said to have described this picture of acute intoxication caused by cerussa (Major 1959:437) but there is no evidence that lead was used for homicidal purposes. The possible impact of chronic lead poisoning (characterized by wrist drop, colic, constipation and pallor) on the Roman Empire is not discussed in this paper. ${ }^{6}$

(ii) Arsenic. Strabo (Geogr. 12.3.40) tells about mines in Mt. Sandaracurgium (Asia Minor) known to have "bad air" which killed the miners, and smelled of sulphur. The ancients called the offending red substance present in lead, silver and goldmines, sandarach or realgar (Plin. NH 34; 54.175-56.178). This was later identified as arsenic sulphide, and used in the colour pigment industry. It is probable that lead compounds aggravated the situation. Arsenic was used extensively as medicine for various ailments. Dioscorides (Osbaldeston 2000:747) also refers to arsenikon found in mines and of value as medicament.

(iii) A variety of substances, translated as gypsum by subsequent authors, are mentioned by Pliny ( $N H$ 28.129). Most were considered innocuous (and used as medicaments), but Dioscorides mentions that one of these, gupsos, taken by mouth caused serious illness associated with a sensation of strangulation (Osbaldeston 2000:756).

(iv) Mercury taken by mouth was said to destroy the intestines (Dioscorides in Osbaldeston 2000:589, 742), but Avicenna later found it harmless (Thompson 1931:99).

(v) Dioscorides (Osbaldeston 2000:740) reviewed the effect on man of a large number of copper-containing substances, and found only one, Malachite (copper silicate) to be potentially fatal.

(vi) The waters of various fountains and rivers in Greece (Thessaly, Arcadia and Macedonia) were considered fatal, and there is a legend that Alexander the Great died after assassins had poisoned him with water from the Styx river at Nonacris in Macedonia (Plut. Alex. 77.3).

6 For a detailed discussion of lead poisoning, cf. i.a. Retief \& Cilliers 2000b (in press). 


\section{Antidotes}

There was an ardent belief in the power of antidotes against venoms, and a plethora of antidotes against specific toxic substances. The vast majority of these were certainly ineffectual. Mithridates VI (120-63 BC) lived in great fear of assassination by poisoning, and invented a "universal" antidote which became widely known as mithridatum. The formula was a closely guarded secret, but when Mithridates was conquered by Pompey, the formula was found to be an unimpressive compound of rue, salt, nuts and figs. In order to sustain the reputation, the formula was expanded progressively - and Galen's prescription eventually consisted of 75 substances (including viper's flesh) (Smith 1952:155). Mithridatum, and the related theriac, remained popular until at least the 18th century. They appear to have done no harm (Smith 1952:155; Kaufman 1932:163-165; Horstmanshoff 1992:42; Nutton 1985:139-143).

In the heyday of poisoning in ancient Rome these remedies were regularly taken by those who considered themselves potential victims. Suetonius (Nero 33.3 and 34) claimed that Nero could not poison his mother, Agrippina, because of the antidotes she took. It was said that Marcus Aurelius took a daily dose of a special theriac, containing cinnamon, and that Galen had the task of preparing the emperor's theriac (Nutton 1985:142). It is clear, however, that there was a wide variety of prescriptions all bearing the common name of theriac or mithridatum (Nutton 1985:142-143) - and all probably equally ineffectual.

\section{Poisons used}

In the vast majority of poisonings recorded in ancient Rome, we do not know the nature of the poison(s) used. However, in some of the following instances, ${ }^{7}$ specific poisons were mentioned:

Recorded incidences in ancient Rome commenced in $331 \mathrm{BC}$ with suspected mass poisoning by a large number of women (Livy 8.18). Comparable episodes followed in 184 and $180 \mathrm{BC}$ (Livy 40.37 and 43). Mass suicide of Capuan senators occurred in 211 BC (Livy 26.13-14). The tragic saga of Sophonisba's death by poison in Carthage (203 BC) (Livy 30.12-15) was followed by the poisoning of two exconsuls by their wives (154 BC) (Livy Periochae 48). Caesar wrote that the British king, Catuvolcus, committed suicide by drinking the sap of the Yew tree (Frohne \& Pfander 1983:223). Cicero mentioned various episodes of poisoning in his judicial orations in defence of Caelius and Cluentius (Pro Cluentio 30, 31 and 47). It is likely that Cleopatra committed suicide by poison in 30 BC (Retief \& Cilliers 1999:8-11).

During the reign of Augustus (27 BC-AD 14) his formidable wife Livia was said by Dio Cassius (56.30.2) to have poisoned various of the emperor's grandchildren and that she might even have poisoned her husband. Asprenas was accused of poisoning 30 guests (Pliny $N H$ 35.164), and the notorious poisoners, Apollodorus and Canidia, who according to Horace (Sat. 2.1.56) favoured hemlock in honey, plied their trade.

A detailed discussion of the incidents of poisoning is given by Retief \& Cilliers (2000a:10-17). 
Drusus, the son of Tiberius (AD 14-37) was poisoned by Sejanus, Prefect of the Praetorian Guard (Tac. Ann. 4.8), and Piso was accused of poisoning Germanicus with the help of a known poisoner, Martina (who then committed suicide) (Tac. Ann. 3.12-25). Many persons accused during mass trials for treason, committed suicide by poisoning (Tac. Ann. 6.40).

Gaius (Caligula) (37-41) collected poisons and killed gladiators, jockeys and horses in an insane attempt to manipulate these sports for his benefit (Dio Cassius 69.14). The satirist, Juvenal, claimed that his insanity was the result of a love-potion administered by his wife, Caesonia (Sat.6.610-626).

Claudius (41-54) probably suffered from cerebral palsy, but proved an unexpectedly efficient emperor, who destroyed Caligula's poisons (Dio Cassius 59.14). He was eventually poisoned by his second wife, Agrippina, with poisonous or poisoned mushrooms supplied by the poisoner Locusta (Suet. Claud. 44).

Nero (54-68) was considered to have been responsible, directly or indirectly, for the death (by poison) of his stepbrother, Britannicus (Dio Cassius 61.7.4), Silanus, governor of Asia (Dio Cassius 61.6.4), Domitia, his aunt, whose riches he desired (Suet. Nero 34), Burrus, Prefect of the Praetorian Guard (Suet. Nero 35.5), and Pallas, Doryphorus and other freedmen (Tac. Ann. 14.65). He contemplated poisoning the whole Senate (Suet. Nero 33.3 and 34) and his mother Agrippina (Tac. Ann. 14.3; he eventually had her brutally murdered). His poisons were usually prepared by the condemned poisoner, Locusta, whom he pardoned (Suet. Nero 33.3). His tutor, the philosopher Seneca, was forced to commit suicide, but the poison (hemlock) taken did not kill him, and he was eventually smothered in a steam bath (Tac. Ann. 15.60$62)$.

Vitellius (69) poisoned numerous noble friends, and probably his mother (Suet. Vitellius 14).

Domitian (81-96) was accused (probably wrongly) of poisoning with sea-hare his brother Titus (who died unexpectedly at the age of 42, probably of malaria), and Agricola, governor of Britain (Tac. Agr. 43).

Hadrian (117-138) possibly killed his wife, Sabina. His adopted son, Commodus, died of an overdose of medicine. The senator Servianus was forced to commit suicide by poison (Spartianus Hadr. 23-26).

Commodus (180-192) poisoned Motilenus, Prefect of the Praetorian Guard with poisoned figs, and was unsuccessfully poisoned by his favourite concubine, Marcia. He was then strangled (Lampridius Comm. 9).

\section{Discussion}

The ambiguity inherent in the words venenum and pharmakon shows that the difference between remedy and poison did not lie in the substance itself, but in the dosage. ${ }^{8}$ This is clearly illustrated by Dioscorides in his Materia Medica IV.64 where he describes the properties, actions and uses of the opium poppy (papaver

8 Cf. too Horstmanshoff 1999:45, 49: "the distinction...between an emetic or laxative and a poison was a gradual one", and "the various poisons are practically all substances which can also be used as medicines". 
somniferum), widely employed as a soporific and analgesic as well as an aid to digestion. However, he cautions that if administered in a more concentrated form and greater dosage, it plunges the patient into lethargy and stupor and can even kill. ${ }^{9}$ Another example of a deadly poison which can also be used as a cure, is Pliny's discussion of the medicinal use of aconite, which "when given in warm wine...counteracts scorpion-stings" ( $N H$ 27.5). We are, however, not informed whether the patient survived the dosage of aconite!

Although deliberate poisoning was common in Rome, it is also true that fortuitous poisoning caused by ignorance regarding the actions of medicaments taken for illness, probably occurred often. Pliny ( $N H$ 29.20) said that accepting drugs from herbalists and drug-pedlars was tantamount to committing suicide, while Galen's scathing comments about the therapeutic abilities of his colleagues put physicians of his time in a bad light (Christie 1987:440-449). Although history tells us of honourable doctors who refused to take part in poisoning (Spartianus Hadr. 23-26), there is also ample evidence of physicians who did take part in murder by poison, e.g. those involved in the deaths of Claudius, and Burrus and Domitia mentioned above.

Poisons and poisoning were of course intricately interwoven with the prevailing Mediterranean culture, steeped in superstition, fear and mythology. At a time when it was virtually impossible to diagnose poisoning retrospectively, accusations of poisoning could rarely be proved or disproved. Post mortem changes considered typical of poisoning, e.g. darkening of the skin, and early bloating but delayed putrefaction, were hardly reliable. One must assume that many victims accused (and even executed) were indeed innocent. Horstmanshoff (1992: 35-36) points out that the ancients differentiated between three kinds of poisons, namely acute poisons killing rapidly, chronic poisons causing physical deterioration, and chronic poisons causing mental deterioration. Professional poisoners like Locusta were often requested by her clients to prepare such poisons to suit their specific needs.

Although a large number of poisonous substances were known in ancient Rome, as indicated by Pliny, Dioscorides, Scribonius, Nicander and others, it would seem that poisons of plant (or rarely animal) origin were preferred by poisoners (Kaufman 1932:161-164). Much has been written about chronic lead poisoning of environmental origin in ancient Rome, but we found no evidence of deliberate lead poisoning (Retief \& Cilliers 2000b). Poisons were usually administered with food or drink - and for this reason official tasters, praegustatores (slaves or freedmen), were employed by the nobility and wealthy. They became so common that they formed a collegium with a procurator praegustatorum (Horstmanshoff 1992:36). Poisons were occasionally also administered by way of enemas (Suet. Claud. 44) and poisoned needles (Dio Cassius 61.7.4; 67.11.6). Tacitus (Ann. 12.66-67) claims that Claudius was finally killed by his physician, Xenophon, who tickled his throat with a poisoned feather.

The survey of recorded crimes by poison underlines the pervasive influence of contemporary socio-political circumstances. Incidents of mass poisoning in early

For a more detailed discussion cf. Scarborough 1996-1997. 
Rome usually coincided with crises such as wars and epidemics; superstition and the belief that scapegoats would solve the problem, would have been determining factors. This phase was gradually superseded by a very well-documented era in which countless individual cases of poisoning are reported, and which reached a peak during the reign of the Julio-Claudian emperors in 1st century AD Ambition and political intrigues would have played an important role during this politically unstable period. During the reign of the so-called Five Good Emperors in the 2nd century AD, commonly regarded as the most prosperous period in Roman history, there is a significant decline in poisoning and suicides by poison. Granted that this period is less well-documented, the political stability of this period which would have brought a greater degree of peace of mind, could have been a determining factor for the decline in violent deaths.

\section{BIBLIOGRAPHY}

Bloch, H 1987. Poisons and poisoning. J.National Med. Assoc. 79(9):761-763.

Christie, R V. 1987. Galen on Erasistratus. Perspectives in biology and medicine 30:440-449.

Frohne, D \& Pfander, H J 1983. A colour atlas of poisonous plants. London: Wolfe Science Books.

Gilman, A G, Goodman L S, Rall, T W \& Murad F 1985. The pharmacological basis of therapeutics. 7th ed. New York: McMillan.

Guthrie D 1958. A history of medicine. London.

Horstmanshoff, H J F 1992. Gemeen goed. Lampas 25.1:32-55.

Horstmanshoff, H J F 1999. Ancient medicine between hope and fear: Medicament, magic and poison in the Roman Empire. European Review 7(1):37-51.

Hughes-Hallett, L 1997. Cleopatra: Histories, dreams and distortions. London: Pimlico.

Kaufman, D B 1932. Poisons and poisoning among the Romans. Classical Philology 27:156-167.

Lloyd, G E R (ed.). 1983. Hippocratic writings. London: Penguin Classics.

Major, R H 1959. Classic descriptions of disease. Springfield: Charles C Thomas.

Nutton, V 1985. The drug trade in antiquity. J.Royal Soc. of Med. 78:138-145.

Osbaldeston, T 2000. Dioscorides. De materia medica. Johannesburg: Ibidis.

Retief, F P \& Cilliers, L 1999. Dood van Kleopatra. Geneeskunde 41.1:8-11.

Retief, F P \& Cilliers, L 2000a. Vergiftiging in antieke Rome. Tydskrif vir Natuurwetenskappe en Tegnologie 19(1):19-24.

Retief, F P \& Cilliers, L 2000b. Loodvergiftiging in antieke Rome. Acta Academica (in press).

Rutten, A M G 1997. Ondergang in bedwelming: Drugs en giften in het WestRomeinse Rijk. Rotterdam: Erasmus.

Scarborough, J 1996-1997. The opium poppy in Hellenistic and Roman medicine. Summary in the Society for Ancient Medicine Review 24:103-104. 
Scullard, H H 1982. From the Gracchi to Nero: A history of Rome from 133 B.C. to A.D. 68. London: Methuen.

Sigerist, D 1971. The great doctors. New York: Dover.

Smith, S 1952. Poisons and poisoners through the ages. Medico-Legal Journal 20:153-167.

Thompson, C J S 1931. Poisons and poisoners. New York: McMillan.

Watt, J M \& Breyer-Brandwijk, M G 1962. Medicinal and poisonous plants of Southern and Eastern Africa. Edinburgh \& London: E \& S Livingstone. 